\title{
Die kerk en sy mag in Openbaring 11
}

\author{
Author: \\ Pieter G.R. de Villiers ${ }^{1}$ \\ Affiliation: \\ ${ }^{1}$ Department of Old and New \\ Testament, University of the \\ Free State, South Africa \\ Correspondence to: \\ Pieter de Villiers \\ Email: \\ pgdevilliers@mweb.co.za \\ Postal address: \\ 202 Rozenhof, 165 Dorp \\ Street, Stellenbosch 7600, \\ South Africa \\ Dates: \\ Received: 09 Sept. 2011 \\ Accepted: 17 Dec. 2011 \\ Published: 28 Mar. 2012 \\ How to cite this article: \\ De Villiers, P.G.R., 2012, 'Die \\ kerk en sy mag in Openbaring \\ 11', HTS Teologiese Studies/ \\ Theological Studies 68(1), \\ \#Art. 1176, 10 pages. http:// \\ dx.doi.org/10.4102/hts. \\ v68i1.1176
}

C 2012. The Authors. Licensee: AOSIS OpenJournals. This work is licensed under the Creative Commons Attribution License.
The church and power in Revelation 11. The article discusses the notion of power in the episode of the two witnesses in Revelation 11:4-6 as a point of departure for a reflection on power in early Christian documents. It also aims to determine the meaning of power in terms of a close reading of a specific text so that discussions about its nature and about power in Biblical texts can be rooted in firm evidence. This evidence should then, at later stages be further developed with the aid of theoretical models and insights about power. In a first section power in Revelation 11:4-6 is described in terms of the identity and task of the witnesses and in terms of its divine origins, followed in a second part by reflection on the direct references to their power. Special attention is given to some seminal issues about power, namely, its relationship with truth and prophecy, its divine origins, the misuse of power, violence as a response to evil and, finally, its role in the Book of Revelation and Early Christianity.

\section{Inleiding}

Die boek Openbaring is deurspek met verwysings na mag. Dit blyk byvoorbeeld uit die magsterminologie wat herhaaldelik gebruik word in die boek se beskrywings van die belangrikste karakters soos God en Christus en hul bose teenstanders. Enkele pertinente voorbeelde hiervan is Openbaring 1:8 se beskrywing van God as die Almagtige, en Openbaring 12:3-4 se verwysing na die vuurrooi draak wat met ' $n$ magsdaad ' $n$ derde van die sterre op die aarde gooi. Maar nie net die bo-aardse karakters het besondere mag nie. Die skrywer van Openbaring huiwer nie om sy aardse karakters as magsfigure te skilder nie. Openbaring 11 beeld op 'n meer konkrete vlak die mag van gelowiges op aarde uit waar hulle geskilder word as getuies wat die mag het om hul vyande te verslind, dood te maak, die hemel toe te sluit en om die aarde met plae te tref (Op 11:5-6). ${ }^{1}$ In hierdie verse word mag uitdruklik genoem, en dan heel opvallend ook verbind met sekere gewelddadige aksies asof dit die mees vanselfsprekende saak is.

Die episode oor die twee getuies in Openbaring 11 kan uit die aard van hierdie verwysings verskeie insigte bied in die aard van mag in die vroeg-Christelike geloofsgemeenskap. Hoe belangrik dit is om hierdie inligting te ondersoek, is duidelik uit die feit dat mag soms in die konteks van geweld ingetrek word en dus problematies kan word. Daarmee word die vraag opgeroep hoe vroegChristelike skrywers oor mag gedink het, veral in hulle konteks van ekstreme gesagsfigure soos die Romeinse keiser, die plaaslike politieke heersers en selfs magtige instansies soos leiers binne die Joodse gemeenskappe. Hierdie vraag word ook belangrik om te verstaan wat die verhouding van mag tot geweld is en hoe gewelddadig gelowiges was. Uiteindelik sou sulke inligting ook vergelyk moet word met die skynbare magteloosheid van Christus se kruisdood en die aardse Jesus se negatiewe uitsprake oor mag (bv. Lk 22:25-26). Sulke en ander pertinente vrae kan vanuit 'n besinning oor Openbaring 11 sinvol belig word.

Enkele opmerkings oor die aard van hierdie hoofstuk in Openbaring is belangrik voordat die verwysings na mag daarin geïnterpreteer word. Openbaring 11 word dikwels as 'n onsamehangende en soms selfs onbelangrike deel van Openbaring beskryf. Lohmeyer (1953:87) byvoorbeeld, skryf, 'Seinem Inhalte nach gehört das Kapitel, im einzelnen wie in seinem Zusammenhang nach vor- und rückwärts betrachtet, zu den dunkelsten Abschnitten der Apc.' Ander interpreteerders meen daarom dat Openbaring 11 nie veel waarde het nie. In sy insigryke kommentaar skryf Kiddle (1946:174) dat Openbaring 11 so moeilik is dat 'the failure to find a solution has induced most commentators to assume that it is of relative unimportance.'

Hierdie ontoeganklikheid is onder andere toegeskryf aan die verwarrende vorm van die gedeelte wat, volgens hulle, die gevolg was van Johannes se onvermoë om 'n bron van hom op 'n samehangende manier in sy boek op te neem. Gevolglik word die hoofstuk as sinloos beskou, as ' $n$ afwyking van die tema van die boek en as 'n indringer-teks wat die gang van die verhaal

1.Die teenpool van die twee getuies is die twee diere wat as volgelinge van die draak onder andere die mag het om mense dood te maak wat nie die Bose wil aanbid nie (Op 11:15). 
versteur. As gevolg hiervan kan dit maklik gebeur dat die hoofstuk se besondere waarde vir besinning oor mag nie behoorlik gewaardeer word nie.

Die interpretasie-geskiedenis van die gedeelte toon inderdaad hoe uiteenlopend die gedeelte verstaan word en hoe dit as 'n verwarrende, gefragmenteerde teks gelees is. Die baie kort en vreemde episode van die meting van die tempel in Openbaring 11:1-2 en die daaropvolgende vertelling oor die profetiese bediening van die twee getuies in Openbaring 11:3-13 word byvoorbeeld in die navorsing as onsamehangend en heel los van mekaar gelees. Die verwarring blyk ook uit die manier waarop die twee gedeeltes op presies die teenoorgestelde maniere geïnterpreteer word, soos nou eers aangetoon moet word.

Die kontrasterende lesings hang ten nouste saam met die manier waarop die teks óf simbolies, óf histories gelees word. Terwyl byvoorbeeld die meting van die tempel meestal simbolies gelees word, word die verhaal oor die twee profete histories en letterlik gelees, ${ }^{2}$ met vele voorstelle vir moontlike historiese referente vir die twee profete.

In die eerste, enigmatiese deel van Openbaring 11:1, ontvang die siener ' $n$ meetstok om die tempel met sy altaar en aanbidders te meet. Dit word dikwels beskou as dieselfde simboliese handeling van beskerming teen die komende aanslag van die Bose as die verseëling van gelowiges in Openbaring 7:3-8. ${ }^{3} \mathrm{Na}$ die opmerking volg 'n verdere opdrag in Openbaring 11:2 aan die siener om, nie die voorhof te meet nie. Dit word oorgegee aan die heidene wat 'die heilige stad'4 vir 42 maande ( 3 en ' $n$ halwe jaar; 1260 dae) sal beset en vertrap.

Na hierdie deel volg ' $n$ skynbaar onverwante verhaal van twee profete wat mag ontvang om reën teen te hou, water in bloed te verander en die aarde met plae te slaan. Die logiese verband met die voorafgaande verhaal is vir vele uitleggers duister. Hierdie twee profete is twee getuies wat sak en as dra en soos twee olyfbome en kandelare voor God staan. Hulle getuig vir dieselfde tydperk as die besetting van die stad en word dan deur die dier uit die afgrond doodgemaak. Vreemd genoeg, speel die dier geen verdere rol in die verhaal nie. ${ }^{5}$ In nog 'n vreemde wending, staan hierdie profete, wie se lyke tot vreugde van die inwoners ${ }^{6}$ op die straat van die

2.Lohmeyer (1953:89) beskryf die getuies as 'übermenschliche Wesen, keine Nachtstellung trifft sie.' Omdat 'keinerlei zeitgeschichtliche Beziehungen deutlich' is, is, volgens hom, enige historiese verwysings na die Romeine en hul leërs uit is, is, volgens hom, enige historiese verwysings na die Romeine en hul leers uit
alle volke, ongegrond. Hulle beskrywing is dus 'tiefer mythologisch gefärbt.' Vir ' $n$ bespreking van simboliek in Openbaring, kyk De Villiers (1988).

3.Die Bybelse agtergrond hiervoor is te vind in Esegiël 40:3-20, maar kyk ook 1 Henog $61: 1-5$. Vergelyk verder ook die bespreking in Bauckham (1993:272-273). Hy interpreter hierdie gedeelte as: 'The church will be kept safe in its hidden spiritual reality, while suffering persecution and martyrdom. This is partially parallel, using different imagery, to the vision of chapter 7 , where the servants of God are kept safe by the seal on their foreheads, but suffer martyrdom.

4.Oor die identiteit van die stad loop menings ook uiteen. Jerusalem as tempelstad is 'n gewilde keuse (Lohmeyer 1953:89).

5.Kyk Lohmeyer (1953:89) - hy wys daarop dat die ruimte vir handeling in Openbaring 11 die stad is, maar in hoofstuk 12 heel ander plekke - wat die samehang nog onduideliker maak. Kyk ook Aune (1998:616-617).

6.Beale (1999:595) beskryf die frase 'inwoners van die aarde' as ' $n$ tegniese begrip wat dwarsdeur die boek verwys na ongelowiges wat onder die goddelike oordee staan omdat hulle gelowiges vervolg. Kyk Openbaring 6:10; 8:13 stad laat lê is, na drie en 'n halwe dag deur die inademing van 'n goddelike gees op ten aanskoue van die hele wêreld. $\mathrm{Na}$ hulle hemelvaart, tref ' $\mathrm{n}$ groot aardbewing die stad, vernietig ' $n$ tiende daarvan en dood 7000 voordat ' $n$ res tot bekering kom.

Hierdie verhaal oor die getuies word dikwels histories gelees en verbind met sulke figure soos Petrus en Paulus; Johannes en Jesus. Hoe meerduidig die teks is, blyk egter daaruit dat sommige eksegete die getuies simbolies lees as referente vir eskatologiese figure (Aune 1998:598-603; Prigent 2001:165).

Hiermee is reeds ' $n$ aanduiding gegee watter uiteenlopende interpretasies van Openbaring 11 in die verloop van die navorsingsgeskiedenis gegee is. 'n Presiese analise van die hoofstuk sal egter bevestig dat dit ' $n$ belangrike sleutel bied tot Johannes se werk as geheel, dat dit veel meer koherent en betekenisvol is as wat soms aanvaar is, en dat dit op hierdie samehangende manier op 'n besondere manier fokus op die tema van mag. In die sin werp die gedeelte ' $n$ ander lig op die oënskynlike magteloosheid van gelowiges teenoor die bose magte aan wie hulle, volgens die res van die verhaal, oorgelewer word.

\section{Literêre aard en funksie}

TerwylKiddle(1946:174) beklemtoon hoe moeilik die gedeelte is, onderstreep hy egter dat die hoofstuk ook the most important in the whole book of Revelation' is. ' $\mathrm{n}$ Analise van die verhaallyn toon dat hy gelyk het. In die groter raamwerk van die boek speel Openbaring 11 inderdaad 'n belangrike rol. Dit volg op en hang ten nouste saam met Openbaring 10 waarin die siener in sy tweede groot visioen die opdrag ontvang om te profeteer en daarmee die res van die boek inlei.? Johannes struktureer met hierdie tweede visioen die tweede hoofdeel van sy boek waarin die konflik tussen die kerk en die bose beskryf word as die bose triade van die draak en twee beeste wat uiteindelik gelowiges in uitsonderlike magsgrepe vervolg. Terwyl Openbaring 12 hierdie geskiedenis van die draak se magsvergrype begin vertel, is Openbaring 11 'n voorbereidende gedeelte waarin die profetiese taak van die twee getuies as die kerk binne die konteks van die groot stad uitgespel word en daarmee gekontrasteer word. Openbaring skets daardeur die raamwerk waarbinne die aanslag van die Bose verstaan moet word: teenoor die magsvergrype van die bose triade staan die getuies as simbool van die kerk met hul eie magsoptrede. Openbaring 11 het dus, soos die verhaallyn uitwys, 'n belangrike rol in die boek as geheel. Daarom is dit ook veelseggend dat juis in hierdie belangrike hoofstuk die motief van mag so 'n prominente rol speel. Openbaring 10 en 11 as middelstuk oor die profetiese oordeelsverkondiging en die goddelike heilshandeling vorm die oorgang tot die finale drama wat met Openbaring 12 begin waarin die profetiese magstryd van die kerk teen die bose magte, die versinnebeelding van die dryfveer vir die groot stad se reaksie op die getuienis, verder uitgebeeld sal word.$^{8}$

7.Die eerste visioen oor die Een soos ' $n$ Menseseun is in Openbaring 1:9-20

8.Lohmeyer (1953:90-91). 
Met hierdie middelstuk van Openbaring 10-11 as oorgang kom daar verder ook afronding aan die eerste deel met sy twee septette van seëls (Op 6) en trompette (Op 8-9) waarin die oordeel oor mense beskryf word weens hulle versuim om tot bekering te kom. Die laaste opmerking voor Openbaring $10-11$ is juis dat mense hulle aan vele vorme van afgodery skuldig gemaak het, maar dat hulle hul ook nie bekeer het van 'moord, towery, onsedelikheid en diefstal' nie (Op 9:20-21). Terwyl gelowiges in die eerste deel hoofsaaklik passief toegekyk het hoe God oordeel (die sewe seëls en die sewe trompette) is hulle in die middelstuk vir die eerste keer aktief betrokke deur hul profesie en magsdade teenoor die ongelowige stad. Die gevolge van hul magsoptrede is opvallend. Hulle getuienis is so sterk dat vir die eerste keer in Openbaring ten minste ' $n$ deel van die wêreld tot bekering kom (Op 11:13).

In die laaste deel van Openbaring is die gelowiges se opponente die bose triade en die prostituut, wat die belangrikste bose karakters in die boek is en wat ' $n$ titaniese magstryd voer met die Lam en sy volgeling: een van die mees pregnante oomblikke in die narratief is byvoorbeeld te vind in Openbaring 13:7 waar die motief van mag pertinent uitgewerk word. Die dier uit die see het volgens die uitspraak 'mag' ontvang om teen die gelowiges oorlog te maak en hulle te oorwin en hy het gesag oor elke stam, volk, taal en nasie ontvang wat hom aanbid.

Teenoor die standpunt dat Openbaring 11 'n onsamehangende, onbelangrike invoeging is, moet die hoofstuk eerder verstaan word as ' $n$ sleutelteks in die verhaallyn van die boek waarin die motief van mag 'n sentrale rol speel. Dit pas goed in die teks as geheel in en dit berei die toneel voor vir die groot magsaanslag teen die kerk wat in die tweede helfte van die boek uitgebeeld word. Die netjiese komposisie word bevestig deur die interne samehang wat Openbaring 11 toon. Dit vorm ' $n$ duidelike eenheid wat uit vier gedeeltes bestaan: voordat die twee getuies met hul bediening begin, word die goddelike beskerming oor hulle uitgespel deur die meet van die tempel en sy aanbidders (A). Die res van die verhaal vertel van hul profetiese taak. Eers word die mag van die profete beskryf (B). Daarna word hul dood en hul skynbare onmag voor die dier in C uitgebeeld. In D en D1 word die gevolge uitgespel: hul lyke lê in die straat tot groot blydskap van die volkere. Dan volg hul opstanding (C1), waarna die vernietiging en bekering van hul opponente vertel word (B1). Hulle geskiedenis word in vers 14 as die tweede weë beskryf (A1). Die netjies gestruktureerde, logiese verhaal is deurtrek met verskeie motiewe en direkte uitsprake oor die uitsonderlike mag, soos nou uitgespel moet word.

Die verhaallyn is origens deurtrek met beskrywings oor die groot magstryd tussen God en die Bose. Die draak, byvoorbeeld, word in Openbaring 12 uitgebeeld as die een wat in die hemel oorlog met Migael en die engele gevoer het en toe op die aarde neergewerp is, waar hy sy magstryd voortsit deur die vrou en haar kind, verteenwoordigers van die goeie, aan te val. Dit is binne hierdie magstryd wat met groot geweld gepaard gaan, dat Openbaring 11 as sleutelteks inpas. Juis daarom is die gegewens oor mag in die hoofstuk van soveel meer belang as wat normaalweg ingesien word.

\section{Die mag van die getuies as profete}

Die mag van die twee karakters word op 'n direkte wyse in Openbaring 11:6 deur verskeie woorde en motiewe uitgebeeld. Voordat dit in detail ontleed kan word, moet eers op die voorafgaande verwysings na die identiteit en taak van die getuies in Openbaring 11:3-5 gelet word, omdat dit reeds indirek ' $n$ aanduiding van hulle magsposisie gee en omdat ' $n$ sterk magsbewussyn daarin na vore kom.

\section{Mag en waarheid}

Die besondere mag van die twee getuies as simbool van die kerk word in Openbaring ten nouste met waarheid verbind. Wie, soos die kerk, waarheid soek en getuig, besit 'n mag wat onstuitbaar is. Dit geld veral in 'n religieuse sin van die woord. Die waarheid wat God bied bemagtig mense. Die getuies se bewussyn van hul mag as verkondigers van 'n goddelike waarheid is ' $n$ fundamentele uitgangspunt in Openbaring 11 se beskrywing van hul identiteit en taak. Die kerk se mag skuil dus in die kerk se solidariteit met God se waarheid. Met hierdie uitspraak verkry mag veral en by uitstek 'n geestelike karakter waarvan die implikasies verreikend is.

In die eerste plek word die twee getuies in Openbaring 11:1 op ' $n$ besondere manier geïdentifiseer as magsfigure wat ' $n$ lewensbelangrike taak het. Hul mag blyk heel eerstens uit die opvallende getal wat met die getuies verbind word. In Openbaring word dikwels in groot getalle oor gelowiges gepraat: hulle is 144000 (Op 7:1-9) of 'n 'groot menigte' (Op 7:9-17). In Openbaring 11 is daar egter net van 'twee'

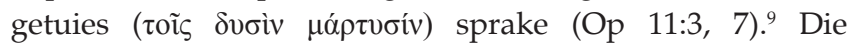
eksplisiete verwysing na 'twee' getuies word berekend opgevolg deur hulle te beskryf as die 'twee' olyfbome en die 'twee' kandelare (Op 11:4). Later in Openbaring 11:10 herhaal Johannes die getal in die pleonastiese beskrywing: oṽ opvallend omdat die argeteks in Sagaria 4:1-14 slegs verwys na een kandelaar met twee olyfbome. Hoewel vele navorsers reken dat die getal twee geskep is onder invloed van die eskatologiese verwagtinge van twee eindfigure in JoodsChristelike kontekste, is die getal eerder 'n aanduiding van die waarheidsgehalte van hul getuienis. ${ }^{10}$ Getuienis is, vanuit hierdie perspektief gesien, eers geldig en geloofwaardig as

9 .Die intens simboliese karakter van die gedeelte blyk daaruit dat die twee getuies beide die olyfbome en die kandelare is. Die stad word byvoorbeeld ook in Openbaring 11:8 Sodom, Egipte en Jerusalem genoem. Lohmeyer (1953:93) skryf tereg dat die $\pi v \varepsilon \cup \mu \alpha \tau i k \tilde{\omega} \varsigma$ [geestelik] van vers 10 nie net belangrik is om die simboliek van die stad in hierdie gedeelte te beskryf nie, maar vir die simboliese karakter van die boek as geheel. Origens word Jerusalem ook in Jesaja 1:9 en Esegiël $16: 46,49$ as Sodom beskryf, sodat die tipering nie heeltemal uniek aan Johannes is nie. In die lig hiervan is dit geforseerd om te sê dat die anaforiese gebruik van die

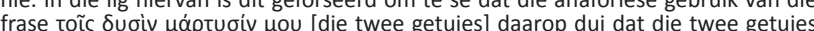
bekend was aan Johannes se lesers, soos by Aune (1998:599).

10.Volgens sommige navorsers herinner die 'twee' getuies aan die eskatologiese verwagting van ' $n$ priesterlike en ' $n$ koninklike Messias in vroeg-Joodse geskrifte, of aan ' $n$ verwagting van Moses en Elia as eskatologiese figure (Luk 9:33). Ander voorstelle is dat die twee wys op die Ou en Nuwe Testament, of die Wet en die voorstelle is dat die twee wys op die Ou en Nuwe Testament, of die Wet en die
Profete soos deur Moses en Elia verteenwoordig (bv. Aune 1998:602). Tog is daar Profete soos deur Moses en Elia verteenwoordig (bv. Aune 1998:602). Tog is daar
in hierdie gedeelte nie sprake van twee verskillende funksies van die getuies nie. 
dit deur ' $n$ tweede persoon gestaaf kan word (kyk bv. Num 35:50; Deut 17:16; 19:15, maar veral ook Matt 18:16; Joh 8:17 en Heb 10:28). ${ }^{11}$ Die getal van twee is dus in die eerste plek 'n aanduiding dat hul getuienis betroubaar en waar is.

Hierdie waarheidskarakter het weer op sy beurt te doen met die bindende karakter van die getuienis. As die getuienis waar is, en dan veral as absolute kontras met die valshede en verleidinge van die Bose, het dit op sy beurt ingrypende gevolge. Dit blyk uit die slothoofstuk van die boek waarin die gesaghebbende karakter van die profetiese getuienis beskryf word. In Openbaring 22:6 sê die engel vir Johannes: 'Hierdie woorde is betroubaar en waar,' waarna die belangrike implikasies uitgespel word met die opmerking dat wie ' $n$ woord van die boek verander, daarmee hul heil op die spel plaas (Op 22:18-19). ${ }^{12}$ So 'n persoon se aandeel aan die boom van die lewe en die stad sal deur God weggeneem word. Die getal twee suggereer dus dat die getuienis in sy waarheidsgehalte bindende mag oor die lewe en dood van sy toehoorders het. Die getuies tree binne hierdie magsfeer op en hulle getuienis moet teen die agtergrond van hierdie bindende mag verstaan word. Terselfdertyd suggereer dit weer eens dat die mag van hulle getuienis onlosmaaklik in 'n religieuse konteks ingebed is (kyk verder hier onder).

\section{Die mag van konfrontasie en teistering}

Hoeveel mag daar in die profete se getuienislewering is, blyk verder ook daaruit dat hulle profesie ' $n$ kwessie van lewe of dood is. Die getuies lewer hulle betroubare, magtige getuies teenoor die Bose as lewensvernietigende mag. Die stad wat die getuies aanvat met die ware getuienis van God, is immers hoogs vyandige opponente. Die opponente van die getuies is deur en deur boos, soos uitgewys word deur die konteks van die stad waarin hulle geplaas word. Die getuies tree op in 'n stad wat in Openbaring 11:8 as driedubbel boos beskryf word deurdat hulle beskryf word as Sodom, Egipte en die plek waar die Here gekruisig is. Hierdie begrippe simboliseer die tradisionele vyande van God wat God se volk vervolg en vernietig. In Openbaring 11 word die mag van die Bose juis daarin geillustreer dat hulle die getuies kan vermoor. Die verhaal beklemtoon die agonistiese verhouding tussen die getuies en die stad wat uitdruklik as 'hulle vyande' beskryf word (Op 11:5 en 12).

Sonder skroom gehoorsaam die twee getuies die 'opdrag' van God om te profeteer teen hulle gevaarlike, magtige vyande en om 'die boodskap' 42 maande lank te verkondig (Op 11:3). In die opsig bly hulle op hul beurt getrou aan die vreeslose karakter van die profete van alle tye. Die skrywer van Openbaring plaas daarmee sy twee karakters in die tradisie van die profetiese verset wat hulle met mag en mening teen afgodery gevoer het. Hoewel die twee predikers aanvanklik eers 'getuies' genoem word, is hulle volgens

11.Waarheid is ' $\mathrm{n}$ sleutelmotief in Openbaring. Nie net is die goddelike figure waa nie, soos blyk uit hul titels, maar ook die woorde van die boek. Vir die kombinasies waarin die woord gebruik word, kyk byvoorbeeld Openbaring 3:7: (met heilig); 3:14: (met betroubaar); 6:10 en 19:11; 21:6; 22:6; 15:3 (met regverdig).

12.Johannes gebruik die eerste en laaste van sy sewe makarismes om sy lesers op die belangrikheid van sy boek te wys (Op 1:3 en 22:7). die skrywer 'profete' wat hul vyande met 'n goddelike, profetiese woord konfronteer. Die profetiese motief word verskeie kere in die gedeelte beklemtoon. Die gedeelte teken hulle in werklikheid meer presies as profete as wat dit hulle as getuies karakteriseer. ${ }^{13}$ In Openbaring 11:10 word na hulle verwys as twee 'profete', hulle 'profeteer' vir 1260 dae (Op 11:3) en geen reën val 'in die dae van hul profesie' nie (Op 11:6). ${ }^{14}$ Wanneer Johannes hulle byvoorbeeld as die twee olyfbome en kandelare beskryf, neem hy simbole uit die proto-apokaliptiese materiaal van Sagaria as profeet oor (kyk verder hier onder). Beckwith (1922) het met insig opgemerk dat die skrywer van Openbaring beklemtoon:

the authority that both the law and the prophets will give to the message of the witnesses whose office it will be to call Israel to repentance in the last times. (bl. 596)

Afgesien van die feit dat die getuies getipeer word in terme van die profete as magsfigure wat in die bedeling voor Christus bemagtig is om die woorde van God te verkondig, is die blote feit dat hulle profete genoem word al ' $n$ aanduiding van die mag wat Johannes as skrywer van die boek Openbaring vir homself toeëien en daarmee aan sy groep toeskryf. Hy haal in Openbaring 16:5-6 'n lied van die engel van die waters aan waarin God as Regverdige en Heilige se oordeel aangekondig word oor mense wat verantwoordelik is vir die vergieting van die bloed van die heiliges en 'die profete'. Deur hierdie oordeel oor vergrype teen profete wys hy op die goddelike beskerming van hom en sy groep as die profete en gelowiges. Hulle kan as profete reken op die 'Almagtige' se beskerming.

Die wyse waarop Johannes die inhoud van die twee getuies se prediking suggereer, onderstreep die magskarakter van die twee getuies verder. Hoewel dit lyk of die inhoud van hulle profetiese verkondiging nie in Openbaring 11 uitgespel word nie, tipeer die sak en as waarmee hulle geklee is hulle as boetepredikers (Op 11:3). ${ }^{15}$ Die sak en as beklemtoon dat die getuies hul vyande oproep tot berou oor hul onbekeerlikheid en hul volharding in afgodery. Die teks wys terselfdertyd ook op die konfronterende aard van hulle profesie, waarmee ook al 'n sekere magsbewussyn veronderstel word. Johannes maak dit elders in sy werk duidelik wanneer hy boete- en oordeelsprediking as prominente motiewe beklemtoon. In die septet van engele in Openbaring 14 verkondig die eerste engel die 'evangelie' aan aardbewoners met die oproep om God te vrees - dit wat juis aan die einde van die verhaal gebeur wanneer die res van die stad aan God die eer bring (Op 11:13). Die derde engel in Openbaring 14 vul hierdie oproep aan met ' $n$ oordeelsverkondiging oor hulle wat die dier en sy beeld aanbid (Op 14:9-11). Hoe sterk die prediking werklik is, blyk uit Johannes se beskrywing hoe die inwoners van die aarde die twee getuies se profesie as 'teistering' (Op

13.Die profete word nie in die teks geïdentifiseer nie. Hulle status en identiteit vind hul mag nie daarin dat hulle belangrike historiese figure is nie, maar in hul goddelike opdrag tot getuienislewering. Hulle word deur God geroep en gegee, soos duidelik blyk wanneer hulle verhaal kort ingelei word met kai $\delta \omega \omega \sigma \omega[$ [en ek sal gee] (Op 11:3).

14.Sy boek noem hy 'n paar keer 'n profesie (kyk bv. Op 1:3 en 22:7, 10, 18, 19).

15.Aune (1998:631, kyk ook bl. 611). 
11:10: غ̇ß $\alpha \sigma \alpha ́ v i \sigma \alpha v)$ ervaar en hoe die inwoners selfs, volgens die teks, die dood van die getuies as 'n bevryding van die teistering vier (Op 11:10). ${ }^{16}$

Dit is opvallend hoe relatief min aandag kommentatore aan hierdie frase oor die teistering gee, ${ }^{17}$ of, hoe terloops dit bespreek word, ${ }^{18}$ en dit terwyl die teistering 'n sleutelmotief in die eskatologiese voorstelling van Johannes is. Daar word byvoorbeeld in Openbaring 14:10-11, 18:4-8 en 20:10 vertel van die teistering van die gelowiges se moordenaars in die eindtyd. ${ }^{19}$

Die inwoners van die aarde word dus volgens Openbaring 11:10 reeds tydens hul aardse bestaan geteister deur die prediking van die getuies, net soos hulle eendag in die eindoordeel geteister sal word, omdat hulle nie op die verkondiging van die evangelie wou reageer nie en omdat hulle die heiliges of profete vermoor het. En tog, hoewel hulle die prediking as teistering ervaar en weet dat die straf van teistering op hulle wag, is hulle nogtans, ironies, vol vertroue dat hul dit kan ontkom. ${ }^{20}$ Rowland (1993) skryf in soortgelyke sin ook sinvol hieroor wanneer hy die teistering met eskatologiese oordeel verbind:

Their [the prophets] actions torment humanity in the way that the plagues of the eschatological judgment do (cf. 16.10). The life of the prophets is not one of niceness and respectability, therefore. They are expected to torment. But that feeling of torment is one that is felt by those who cannot cope with God's justice and prefer not to acknowledge it. It is the torment of the prick of conscience and the dim realization that what is normally seen as acceptable may not in fact be so. (bl. 100)

Dit is op hierdie punt dat die vraag oor die verhouding van mag tot geweld aan die orde kom. Vir sommige navorsers is die getuies se mag gewelddadig, soos blyk wanneer die teistering as vuur en straf beskryf word (Op 11:5). Die getuies het egter, ten spyte van hulle groot mag, volgens die teks nie werklik mense gedood nie. ${ }^{21}$ Die rede is duidelik: die vuur kom immers uit hulle mond, terwyl die water wat in bloed verander word, herinner aan die tien plae as goddelike teistering van Egipte. Daarmee word dus simbolies op die goddelike oordeel oor die Bose gewys. ${ }^{22}$ Intertekstuele verwysings bevestig verder die simboliese karakter van die

16.So intens is die teistering vir die inwoners van die aarde dat hulle blydskap oor hul verlossing met drie frases uitgebeeld word: hulle is bly, verheug en gee aan mekaar geskenke.

17.Die frase word onbespreek gelaat in byvoorbeeld. Beckwith (1922:602-603) Sickenberger(1942), Lohmeyer(1953), Caird (1966:138), Beasley-Murray (1974:186), Müller (1995:215) en Knight (1999:87).

18.Gießen (1997:256), byvoorbeeld, verbind die teistering kortliks met die plae in verse 3-7a. Kyk ook die kriptiese opmerkings in Beale (1999:596)

19.Een van die weinige opmerkings is te vind by Osborne (2002:429).

20.Kyk ook die boeiende opmerkings van Rowland (1993:101) wat ook ' $n$ ironiese toon in die gedeelte vind: die inwoners van die stad misgis hulle deur te dink dat die verwydering van die getuies die einde van hul teistering is. Hy wys op kontemporêre voorbeelde van soortgelyke minagting vir die menswaardigheid van 'n mens se vyande.

21.Die enigste slagoffers in hierdie gedeelte is die 7000 wat in die aardbewing omkom (Op 11:13).

22.Ook hier moet in gedagte gehou word hoe Johannes sy hoorders herinner dat God vir iemand wat iets byvoeg of wegneem, 'plae' sal byvoeg en die ewige lewe sal ontsê (Op 22:18-19). Teenstand teen die profesie bring dus die straf van die plaewat ook in Openbaring 11 die geval is. vuur. Die vuur se sinspeling op Jeremia 5:14, wat die argeteks is, is onmiskenbaar: 'Omdat hulle dit gesê het, maak Ek my woorde in jou mond 'n vuur en hierdie volk hout, sodat die vuur hulle verteer. ${ }^{23}$

Ander tekste suggereer ook dat die optrede van die twee getuies nie te gou letterlik as gewelddadig beskou moet word nie. In die resepsie-geskiedenis van sulke apokaliptiese motiewe word die neiging tot ' $\mathrm{n}$ spiritualisering van mag duidelik gesien, soos byvoorbeeld in die Joodse apokalips, 4 Esra 13:10, waar die Messias 'n stroom vuur uit sy mond stuur, 'n vlam van sy lippe en storm van vonke van sy tong. In 4 Esra 13:37-38 word hierdie beeld uitdruklik simbolies verduidelik: die storm van vonke is die teregwysing vir die volke se goddeloosheid, die bestraffing vir hul bose gedagtes en pyniging en die vuur is die vernietiging deur die wet. Elke keer beklemtoon die gedeelte in 4 Esra dus dat hierdie drie elemente simbole is. ${ }^{24}$

Hierdie insig word deur ander tradisies bevestig. Daar is 'n sterk vroeg-Christelike tradisie wat die magtige oordeelprediking juis nie letterlik wil verstaan nie, soos Lukas 9:51-56 se verset teen letterlike geweld uitwys. In die episode wil Jakobus en Johannes vuur van die hemel laat neerdaal om die Samaritane te verteer weens hulle weiering om Jesus te ontvang. In reaksie hierop weier Jesus hulle versoek en wys op die heilskarakter van sy prediking.

Die vroeë kommentatore op Openbaring het dit ook uitgewys. Die Latynse kommentator op Openbaring, Victorinus, het vroeg reeds opgemerk dat die vuur in Openbaring 11:5 wys op die mag van die woord..$^{25}$ Hierdie simboliese interpretasie word deur ander aspekte van die teks ondersteun, soos reeds aangetoon. Die gedeelte in Openbaring as fenoteks moet dus teen die agtergrond van hierdie argetekste met hul sterk spiritualisering van die oordeelsmotiewe gelees word.

Die teistering het dus met skerp aanklagte van goddelike oordeel $^{26}$ te doen wat druk op inwoners van die aarde uitoefen. Dieselfde intense druk word elders in Openbaring ook aangedui, maar dan in 'n negatiewe sin vir teenstanders van God. Dit geld byvoorbeeld veral vir die bose karakters: iemand wat mag het, kan immers, in die oë van die skrywer van Openbaring, met arrogante taal ander se lewens ingrypend bepaal. Die dier uit die see sê verskriklike dinge en laster 'terwyl hy twee-en-veertig maande lank gesag uit oefen' (Op 13:5-7). ${ }^{27}$ In Openbaring 13:15 kry die dier uit die aarde mag om die beeld wat hy laat oprig het, te laat praat 23.Aune (1998:613).

24.Vergelyk Aune (1998:614), 'The power of the word of God is expressed in a variety of other ways also, such as the rain that causes seed to germinate (Isa 55:11) and other metaphors (Isa 9:8; 11:4).' Dit word ondersteun deur die intertekstuele lyne, want die beskrywing herinner aan die Bybelse verhaal van Elia: Elia het die mag gehad om deur vuur te vernietig en reën terug te hou om mense tot inkeer te bring (1 Kon 17:1; 2 Kon 1:10 e.v.; Luk 4:25)

25.Potestatem verbi dicit; Comm.in Apoc.11.2. Vergelyk verder die parallel by 2 Henog 1:5 en 3 Henog 19:25; 22:4. Lactantius, Div. Inst. 7.17.2. Hoewel dit onder invloed van Openbaring kon ontstaan het, bevestig dit die tendens.

26.Giblin (1991:115) praat van 'unbearable accusations'.

27.Kyk Daniël 7:25; 12:7. Kyk ook Openbaring 11:3; 12:6, 14. Satake (1966:119-133) meen dat die twee getuies nie ingestel is op bekeringsprediking nie, maar op die oordeel. Hulle is agente van God in die voltrekking van die oordeel. 
en mense wat nie die beeld aanbid nie, te laat doodmaak. Dit is die teenpool hiervan wanneer die skrywer vertel hoe die getuies se profetiese prediking die inwoners van die aarde onder groot druk plaas.

\section{Die goddelike herkoms van mag}

Daar is ' $n$ verdere dimensie van mag wat veral die geestelike karakter daarvan uitwys. Dit kom na vore in die subtiele manier waarop in Openbaring 11:3 die twee getuies as 'my' getuies beskryf word. Die profete se getuienis is dus magtig vanweë die goddelike herkoms daarvan. Dit is die implikasies van die 'my' as besitlike voornaamwoord waarmee die getuies verbind word.

Op die oog af is dit nie duidelik na wie hierdie 'my' verwys nie. Dit kan egter nie God of Christus wees nie, want die gedeelte verwys na hulle in die derde persoon (Op 11:8, 11, 12). Dit kan dus na die Heilige Gees verwys as die Een wat die profete inspireer om namens God te praat, maar wat ook in elk van die sewe briewe met die gemeentes praat (Op 2:7, 11, 17, 29; 3:6, 13, 22; 14:13; 22:17; kyk Giblin 1991:113). Dit is die Gees wat, saam met die bruid, ook met die lesers van die boek praat (Op 22:17). ${ }^{28}$ Hiermee word uitgewys dat die getuienis ' $n$ goddelike oorsprong het wat direk kontrasteer met die verskriklike, lasterlike woorde van die Bose wat inwoners van die aarde op 'n destruktiewe, dodelike manier mislei tot afgodery en verdere afgodery tot stand bring (Op $13: 5-6 ; 14-17) .^{29}$

Die goddelike herkoms van die getuienis word verder onderstreep deur die belangrike frase dat die twee getuies 'voor die Here van die aarde staan' (Op 11:4)..$^{30}$ Hulle word daarmee met die setel van mag verbind, want hulle staan voor die troon, maar hulle staan ook by die sewe geeste voor die troon (Op 1:4). Hulle werk en boodskap word deur die mag van God se Gees gedra, maar dit word ook gekarakteriseer deur hul bestaan in die teenwoordigheid van God. Die verhaal van die getuies word, soos 'n literêre analise uitwys, omraam deur die betrokkenheid van die God van die hemel en die aarde. Aan die einde van die gedeelte word hierdie insig naamlik uitgewerk wanneer vertel word van die bekering van die volke en hoe hulle 'die God van die hemel' verheerlik (Op 11:13).

Die verbintenis van die getuienis met die mag van God is des te meer opvallend in die lig van hoe sterk God se mag in Openbaring 11 uitgespel word. Verskillende fasette van die verhaal wys hierop. Die mees pregnante verwysing na

28.In Openbaring 13:15 word vertel dat almal wat die beeld van die dier aanbid gedood sal word. Hoewel dit nie direk van die twee getuies gesê word dat hulle almal wat God nie aanbid nie, sal doodmaak, word dit wel van God gesê dat God aanhangers van die Bose uiteindelik sal vernietig.

29. Let op die ander kontras: aan die Bose 'word mag gegee' om tekens te doen - soos die twee getuies - en om mense te mislei (Op 13:14). Dit is net vir 42 maande (Op $13: 5)$, sodat ook sy mag afgelei is en tydelik aan hom gegun word.

30.Aune (1998:613). Die frase sinspeel op Sagaria 4:14 met sy verwysing na die eskatologiese getuies. Kyk Openbaring 4:5, 10; 7:15; 22:12 vir 'staan voor' die troon. In Openbaring 8:2 staan die belangrike sewe engele met die sewe trompette voor God. In Openbaring 8:4 word 'voor God' herhaal. Openbaring 7:9 is die enigste ander plek waar iemand (die volkere) 'voor die troon staan.'
God se uitsonderlike mag om 'n skynbaar hopelose situasie om te keer, word in die opstandingsgebeure in Openbaring 11:11 uitgebeeld. Die getuies, reeds drie en ' $n$ halwe dag dood, word deur 'n gees van die lewe uit God uit die dood opgewek. God omvorm die situasie omdat God mag oor die dood het. ${ }^{31}$ God het dus die vermoë om 'n hopelose toestand - selfs van die dood - te transendeer deur lewe te gee. ${ }^{32}$ Die goddelike mag word verder ook bevestig deur die groot aardbewing na die opstanding van die getuies (Op 11:13).

Die mees pregnante perspektief op die goddelike herkoms van die getuienis kom na vore wanneer die goddelike mag aan die einde van hierdie episode uitgebeeld word. Dit word met die afloop daarvan, wanneer die sewende en laaste engel sy trompet blaas, eksplisiet uitgespel: in die danksegging en doksologie wat op die verhaal van die twee getuies volg, aanbid die belangrike karakters van die 24 ouderlinge voor die troon vir God met die woorde: 'Ons dank U, Here God, Pantokrator, dat $\mathrm{U} u$ groot mag aangeneem en as koning geheers het' (Op 11:17, kyk 12:10, maar ook 1:8). ${ }^{33}$ Die frase is deurspek met woorde wat met mag te doen het. God is uiteindelik die enigste een wat mag het. In die gedeelte word

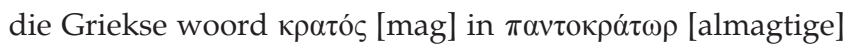
gebruik wat elders in die boek nooit met die Bose of met mense verbind word nie, maar alleen in doksologieë vir God en Christus aangetref word (vgl. Op 1:6; kyk verder hier onder).

Hoewel die getuies dus magtige persone is, is hulle mag gedeel en afgelei. Hulle het alleen mag omdat dit van Godsweë aan hulle verleen word. Die eintlik maghebber is God wat alleen oor mag beskik. Die mag van God geld selfs oor lewe en dood. God deel die mag met hulle wat die goddelike waarheid verkondig. ${ }^{34}$ God wat die Skepper is, is in Openbaring daarom ook die Pantokrator, die enigste Een wat ware mag besit (Op 1:8).

Hierdie siening van die ware setel van mag, relativeer enige magsgebruik van gelowiges. Hulle kan alleen mag uitoefen in soverre as wat God dit aan hulle toestaan. Om mag te deel, verskil radikaal van om mag te kan besit en uitdeel. Die kerk leef in sy getuienis nie uit homself nie, het die mag nie in sy eie getuienis gesetel nie, maar ontvang dit in 'n verhouding met God en as gawe en opdrag tot die lewering van getuienis.

31. Hierdie mag is in lyn met die voorstelling van Christus as die Een wat die sleutels van die dood doderyk het $(O p$ 1:18) en as God wat, soos blyk uit die vierde seël in die septet van seëls selfs die dood en die doderyk toelaat om sy oordeel te voltrek.

32. Dit herinner aan die vrou in Openbaring 12 wat ' $n$ kind in die lewe bring, terwyl die draak die kind om die lewe wil bring.

33.In Openbaring 4:11 word gesê dat God waardig is om mag te ontvang omdat God alles geskep het.

34.Decock (2011) verwys na twee soorte geweld in Openbaring: 'There is the ordinary human violence caused by the human means, and this violence is, of course, forbidden by the Law and condemned also in the Apocalypse (Rev 16:6; $21: 8 ; 22: 15)$; it is the kind of violence which destroys creation. The second kind of violence is God's violence, which defends creation. It takes two basic forms, judgment and war (Rev 19:11). The first is already operative in the world through
julions judgment and war (Rev 19:11). The first is already operative in the world through the justice system (Rom 13:1-4) and will be completed before the throne of God (Rev 20:11-15). The second form, that of war, is also operative in the world but in a restrained way at present in the prophetic ministry. This is the kind of "miraculous" violence, which does not operate with the ordinary human means." Hy wys as voorbeeld hiervan na Johannes 18:1-11 en Handelinge 5:1-1. 


\section{Mag as reaksie}

Terwyl die vorige inligting indirek verwys na die mag van die twee getuies in Openbaring 11 soos dit na vore kom in hul identiteit en profetiese taak, word in die gedeelte self direk verwys na hul mag. In der waarheid is die gedeelte so opgebou dat woorde wat met mag te doen het, as sentrale fokus uitgelig word. Dit blyk onmiskenbaar, veral wanneer die vorm van Openbaring 11:4-6 van naderby beskou word.

Die gedeelte vorm 'n netjiese ringkomposisie waarin vier keer uitdruklik na mage verwys word. Hierdie vier uitsprake vorm twee netjiese parallelle pare (A/A1 en B/B1). In die raam van die gedeelte (A en $\mathrm{A} 1$ ) word die twee getuies bekend gestel (en daarmee hul identiteit en taak uitgewerk). In die raam begin beide A en A1 met oṽ $\tau$ oí [hierdie], waarmee hul paralleliteit uitgewys. Dit word versterk deur die feit dat albei 'n verwysing na die aarde bevat. In die middel van die

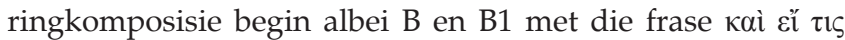

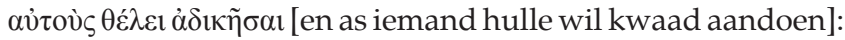

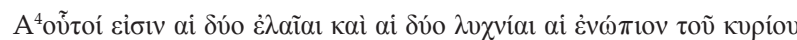
$\tau \tilde{\eta} \varsigma \gamma \tilde{\eta} \varsigma^{35} \dot{\varepsilon} \sigma \tau \tilde{\omega} \tau \varepsilon \varsigma$.

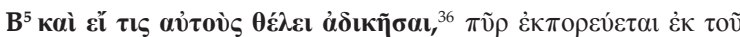

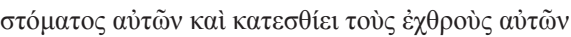

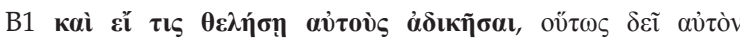

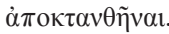

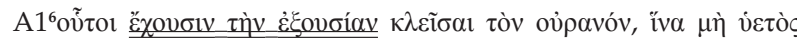

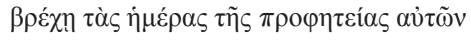

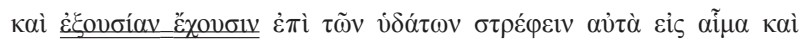

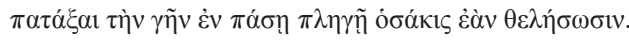

[A Hulle is die twee olfybome en die twee kandelaars wat voor die Here van die aarde staan

B En as iemand hulle wil kwaad aandoen, gaan daar vuur uit hulle mond uit en verteer hulle vyande.

B1 En as iemand hulle wil kwaad aandoen, moet hy op dieselfde manier gedood word.

A1 Hulle het mag om die hemel te sluit, sodat daar in die dae van hulle profesie geen reën val nie.

En hulle het mag oor die waters, om dit in bloed te verander en om die aarde te tref met allerhande plae so dikwels as hulle wil.]

In die ringkomposisie is daar ' $\mathrm{n}$ klimaktiese lyn na A1 waarin

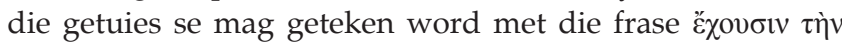
$\dot{\varepsilon} \xi_{0} \sigma \operatorname{í}_{\alpha \nu}$ (v. 6). Die frase word gefokaliseer deurdat dit in die sinsinisiële posisie geplaas word en binne A1 herhaal word. Dit is des te meer opvallend wanneer die klimaktiese plek van A1 in die ringkomposisie uitgewys word. Die vorm van die gedeelte toon naamlik 'n duidelike ontwikkelingslyn. Dit gaan om twee profetiese getuies (A) wie se mag veral na vore kom wanneer hulle aangeval word (B en B1) en aan wie hierdie buitengewone mag tydens hulle profetiese taak toegeken word (A1). Daarmee blyk hoe versigtig Johannes die motief van mag in die hart van hierdie gedeelte plaas.

Mag word nie alleen deur sy goddelike oorsprong bepaal

35.Dit is die enigste plek in Openbaring waar hierdie beskrywing met God verbind word. Origens word daar dikwels van die konings 'van die aarde' gepraat.

36.Die werkwoord beteken om skade aan te doen of te beseer. nie, maar ook deur die objekte waaroor dit beskik. Dit is in Openbaring deurslaggewend dat die mag van die kerk in sy getuienislewering eerstens op die inwoners van die aarde gerig is. Dit uitdruklike verwysings na die mag van die profete in die parallelle paar (B en B1) in die middel van die ringskomposisie verwys na hul mag oor mense. Maar hier is die karakter van die objek 'mense', 'n belangrike aanduiding van die aard van mag omdat hierdie mense gelowiges kwaad wil aandoen. Beide B en B1 word ingelei met die frase: אaì દỉ

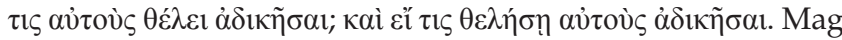
word gebruik teen ander mense wanneer hulle dreigend en lewensvernietigend optree. Die profete het mag om mense wat hulle wil kwaad aandoen, af te weer. Mag funksioneer dus om die skepping en kerk teen destruktiewe optrede af te skerm.

Verskeie ander opmerkings kwalifiseer hul mag: dit is eerstens duidelik dat hier nie sprake is van gewone menslike mag nie. Hulle mag is ' $\mathrm{n}$ geestelike mag. Dit kom na vore in die simboliese beskrywing van die vuur wat uit hul mond kom. Die frase herinner byvoorbeeld sterk aan die swaard wat uit die mond van die Menseseun kom (Op 1:16). Daarmee word weer eens hierdie mag gekwalifiseer as oordeelsprediking - wat die voorafgaande gedeelte oor die sak en as verder kwalifiseer en bevestig. Daar is ook ' $n$ opvallende ooreenkoms van die vuur uit die mond van die getuies met die drie plae van vuur, rook en swael wat uit die bekke van die perde in die sesde trompet kom waarmee hulle, ook in ' $n$ oordeelshandeling, 'n derde van die mensdom doodmaak (Op 9:18-19). Die mag is dus ' $n$ verleende, geestelike mag, in diens van God se stryd teen en veroordeling van die Bose.

Hiermee saam hang die feit dat die twee profete ook besondere mag oor die natuur het, soos blyk uit A1. Hierdie tweede objek vul die 'mense' as objek van magsuitoefening aan. Ook hier word die mag oor die natuur deur ander motiewe verder gekwalifiseer. Hulle het ' $n$ mag, wat kosmies van aard is, want dit word in terme van drie sfere - die hemel, die aarde en die water - uitgebeeld. ${ }^{37}$ Elkeen van die drie plekke waaroor hulle mag het, kan deur hulle negatief aangetas word: hulle kan die reën keer, ${ }^{38}$ hulle kan die waters in bloed verander ${ }^{39}$ en hulle kan die aarde met plae slaan. ${ }^{40}$ Die skeppingsgedagte wat prominent in Openbaring is, word hiermee verbind met die oordeel: die skepping staan in diens van God se mag deur die getuies teen die Bose. God gebruik dus die skepping om die Bose te oordeel.

Dit alles toon dat die mag wat aan die getuies verleen word, reaktief van aard is. Hulle mag het te doen met die vermoë om kwaad teen te staan en te beantwoord met die oordeel.

37.Die mag oor die natuur wat hier uitgebeeld word in terme van drie sfere, word in Openbaring 14:7 uitdruklik met aanbidding van God en God se skeppingsmag verbind (vgl. ook die 4 sfere in die eerste vier trompette in Openbaring 8:6-13). Daarmee word ook duidelik gemaak hoe die getuies deel in God se ma.6or die skepping.

38.Soos Elia in 1 Konings 17-18.

39.Die eerste plaag - Eksodus 7:14-19; maar kyk ook Openbaring 8:9 en 16:4

40.1 Samuel 4:8; Eksodus 7:14-11:10. 
Mense wat kwaad doen, word daarvoor gestraf. Die optrede van hul teenstanders het dus konsekwensies. Hulle word verantwoordelik gehou vir hul dade van vernietiging. Die mag van die getuies word daardeur 'n spesifieke fokus gegee: hulle ontvang mag om die Bose verantwoordelik vir sy kwaad te hou. Mag word dus deur profetiese verkondiging en deur bemiddeling van die skepping gebruik om destruktiewe mag te stuit.

\section{Grense van mag}

Die spesiale mag van die getuies het egter ook duidelike grense. Hoewel hul mag oorweldigend is, onder andere in die kosmiese aard daarvan, is dit nie willekeurig nie. Die mag bly bestraffend sonder om dwingend te word. Die getuies het nie die vermoë om ander sonder rede tot ' $n$ bepaalde reaksie te dwing nie. Hulle mag word uitgeoefen in reaksie en oordeel oor teenstanders wat hulle kwaad aangedoen het en waar mense weens hul onbekeerlikheid en aanbidding van afgode hulle skuldig aan konkrete moord en bloedvergieting maak (Op 16:6; 21:8; 22:15) ${ }^{41}$ Hulle mag staan in diens van God se bekeringsoproep - hul profetiese getuienis en verkondiging van die evangelie moet mense tot bekering en aanbidding van God beweeg (Op 14:6-7). Daarom word uitdruklik gesê dat hul mag begrens is tot die dae van hul profesie (Op 11:6). Die mag van die profete verskil dus nie wesenlik van die mag van die Een soos ' $n$ Menseseun wat by die deur staan en klop nie (Op. 3).

Hierdie uitbeelding van mag wat begrensd en sonder dwang is kontrasteer met die willekeurige uitoefening van mag deur die dier uit die afgrond, wat vir die eerste keer in Openbaring 11:7 genoem word, en wat, as die beliggaming van die Bose wat God se heilswerk opponeer en tot niet maak, die getuies vermoor. Die aksie van die Bose staan dus in die teken van sinlose, ongemotiveerde geweld, maar veral in die teken van verwerping van en verset teen die evangelie. Hulle boosheid word in die oë van Johannes gedryf deur hul diepe antipatie teenoor God. Dit weer weerspieël op sy beurt die self-gerigtheid van die Bose. Sy motief is om mense tot aanbidding van homself bring. Die Bose soek na self-verheerliking en self-verryking (Op 16:6; 21:8; 22:15) vandaar sy antipatie teenoor die evangelie wat vra dat God alleen aanbid moet word. ${ }^{42}$

Hiermee word die wese van die magstryd in Openbaring aangedui. Die spil van mag draai in Openbaring om egte godsdiens. Die skrywer van Johannes het immers 'n duidelike afkeer aan afgodediens en die immoraliteit wat daarmee gepaard gaan: behalwe vir die wankelmoediges en die ontroues, word losbandiges, moordenaars en onsedelikes, bedrieërs en afgodsdienaars en leuenaars in die vlamme van die swawelpoel gesmyt. Hierdie is die 'tweede dood' (Op 21:8). Die wêreldbevolking word dus verdeel tussen hulle wat vir of teen egte godsdiens is, hulle wat deur die mag van die Bose mislei word en hulle wat God die Almagtige dien.

41.Kyk ook Openbaring $2: 11 ; 6: 6 ; 7: 2,3 ; 9: 4 ; 9: 5 ; 18: 5$ (!); $22: 11$.

42.Die optrede van die twee getuies is dieselfde as sommige profete in die Ou Testament (kyk Eks 7-15; Num 16; 25; 1 Kon 17:11-16; 18:2; 2 Kon 1;2:23-25; Jer $1: 10 ; 28)$. In sommige vroeë tradisies is hierdie tekste se gewelddadige karakter ook bevraagteken. Kyk Allison (2002:459-478).
Dit is op hierdie punt dat die res van die verhaal oor die twee getuies ook belangrik word. In Openbaring 11:1 word naamlik ' $n$ sleutel tot die betekenis van die gedeelte gegee wanneer gelowiges wat deur God beskerm word teen die

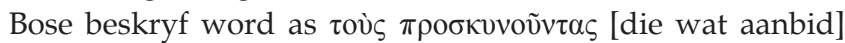
wat in die tempel is. Hierdie Griekse begrip word elders in Openbaring vir egte aanbidding gebruik. Wie God aanbid, word beskerm en ontvang buitengewone mag. Hierdie beskerming kom tot sy volle ontplooing wanneer die twee getuies deur God opgewek word en in die hemel opgeneem word (Op 11:11-12).

Tog het hierdie beskrywing van goddelike mag ook sy skerp kant veral weens latere resepsies wat daarop gestut kan word. Hoewel die getuies se magsdade opgeroep word as 'n reaksie teen die kwaad en onberoulikheid van hul teenstanders, en die geweldstaal simbolies is vir hul strenge oordeelsprediking en 'n waarskuwende oproep tot boetedoening, is dit simboliese taal van bestraffende oordeel wat oop is vir misverstand en misbruik kan word om fisieke geweld te bevorder of om ' $n$ negatiewe, gewelddadige Godsbeeld te artikuleer. ${ }^{43}$

\section{Die Christologiese karakter van mag}

Mag in Openbaring is ten nouste met die figuur van Christus verbind. Die uitbeelding van die getuies se optrede is op die voorbeeld van Christus geskool. Dit beteken dat hul mag deur self-prysgawe gekwalifiseer word. Al is hulle, soos Christus, magsfigure met 'n sterk oordeelsprediking, gebruik hulle nie hul mag tot eie voordeel nie. In die opsig is daar ' $n$ duidelike progressie in die verhaal. Hulle het aanvanklik mag gebruik om die kwaadwilligheid van hul teenstanders te veroordeel en straf. In 'n klimaktiese wending kom hieraan ook 'n einde. Hulle mag weerhou hulle nie daarvan om uiteindelik in navolging van Christus hulself in 'n daad van self-prysgawe aan die dood oor te gee nie. Soos Christus sterf die getuies ook gewelddadig (Op 11:7-8). Hulle het, soos Openbaring 7:14 ook laat blyk, as dié wat uit die 'groot verdrukking' kom, hulle klere wit gemaak in die bloed van die Lam. Hulle word geslag soos die Lam geslag is (Op 5:6, 9). Hierdie magsprysgawe bring vir hulle groter mag: soos Christus bring hulle daad van prysgawe vir hulle die opstanding en hemelvaart (Chevalier 1997:322). Die uitstaande kenmerk van die getuies is immers, in die woorde van Openbaring 12:11: dat hulle 'oorwin deur die bloed van die Lam en deur die woord van hulle getuienis, en hulle het tot die dood toe nie hulle lewens liefgehad nie.' In hierdie konteks pas die beskrywing van die dood en oorwinning van die gelowiges. Die verwysings hierna in Openbaring 12:11 word voorafgegaan deur die doksologie waarin die deurbreek van die mag van Christus gevier word (Op 12:10). Die dood van Christus en opstanding verteenwoordig dus die bekendmaking van die mag van Christus. Met hul eie dood en opstanding volg hulle Christus en deel hulle aan sy heerlikheid.

Maar die mag van Christus as konteks vir Openbaring 11 kry 'n verdere dieper dimensie aan die begin van die boek. 43.Vir die problem oor goddelike geweld, kyk veral Neville (2007:131-161). 
Johannes verbind sy openingsgroet in Openbaring 1 met 'n doksologie. Daarin beskryf hy Jesus as 'die getroue getuie, die eersgeborene uit die dood en die Owerste oor die konings van die aarde.' In die daaropvolgende gedeelte bring hy 'die heerlikheid en die krag' aan hom 'wat ons liefgehad het en ons van ons sonde gewas het in sy bloed en ons gemaak het konings en priesters vir sy God en Vader' (Op 1:5-6). In Openbaring 5:13 volg ' $n$ doksologie wat uitgebreider as hierdie een is, maar wat ook aan die Een op die troon en die Lam gewy word. Ook hier oorheers verwysings na die besonder mag van Christus. Die twee getuies kan deur hul getrouheid aan Christus daarom aan die einde van die tye saam met Hom op dit troon sit (Op 20:3).

Die profetiese getuienis van die getuies is dus geskool op die model van Christus. Daarmee word ' $n$ bepaalde interpretasie-raamwerk op die opmerkings oor hul mag in Openbaring 11:5-6 geplaas. Hulle magsuitoefening kan in kwaliteit nie anders wees as die mag van Christus nie wat beteken dat dit by uitstek ' $n$ geestelike mag is, onder andere gedryf deur die liefde vir sondaars (Op 1:5b). Soos Christus bring hulle ook 'n skerp prediking van oordeel, maar soos Christus is die sterkste uitbeelding van mag die feit dat hulle bereid is om te sterf vir die evangelie en uit liefde vir ander.

Uiteindelik moet die uitbeelding van die getuies dus vanuit Openbaring se missiologiese perspektief verstaan word, veral omdat dit meer lig op die oordeelsmag en -handelinge van God in Openbaring nader verklaar. Die verhaal van die getuies kom tot ' $n$ hoogtepunt in die slotuitspraak dat sommige aan God 'eer gegee het.' Giblin (1991:116) het uitgewys dat Openbaring hiermee profetiese 'oorblyfsel'taal gebruik. Wanneer die profete die oordeel verkondig, is daar 'n klein oorblyfsel wat oorleef en wat hul verhouding met God nuut uitbou (Jes 6:13; Am 5:3; 1 Kon 19:8; vgl. Rom 11:4-5). Hy (1991) merk op:

This passage serves as a vivid, perhaps needed corrective to the pessimistic results of the first woe, in which the rest of mankind was not shocked into repentance, but despaired of life, and to the hellish host introduced by the sixth trumpet, where, expressly, the two-thirds remained unconverted. Likewise, it prepares for further disclosures which imperatively announce the possibilities of a positive response to the Gospel up to the very moment of the final judgment on obdurate wrongdoers. It reaffirms, to be sure, God's vindication of the right way of thinking and acting and his punitive power though not all as hate-inspired or without a persistent appeal for conversion as well as for fidelity. (bl. 116)

Die geestelike impak van die Christologiese uitbeelding van mag kom op 'n ander manier in Openbaring na vore. Vroeg reeds is daar in Openbaring sekere uitsprake wat daarop wys dat die sterk optrede teen nie-gelowiges nie hul vernietiging in gedagte het nie. In Openbaring 3:10, geskryf aan Filadelfia, vir wie God 'liefgehad' het (Op 3:9), word vertel dat God hulle sal bewaar in die uur van beproewing wat oor die hele wêreld sal kom om die bewoners van die aarde op die proef te stel. Die doel van die beproewinge is om mense tot bekering te dryf (Ladd 1972:62; kyk Op 9:20; 16:9 en 11). Die mag van God is ' $n$ straffende mag, wat die heil van mense soek eerder as hulle verwerping. Maar as straffende mag kan dit nie wegskram van sy eie implikasies nie: wie die heil verwerp, sal uiteindelik onder die gevolge van sy of haar keuse ly.

\section{Erkenning Mededingende belange}

Die outeur verklaar dat hy geen finansiële of persoonlike verbintenis het met enige party wat hom nadelig kon beïnvloed in die skryf van hierdie artikel.

\section{Literatuurverwysings}

Allison, D.C. Jr, 2002, 'Rejecting Violent Judgment: Luke 9:52-56 and Its Relatives', Journal of Biblical Literature 121, 459-478. http://dx.doi.org/10.2307/3268156

Aune, D., 1998, Revelation 6-16, Word, Dallas. (Word Biblical Commentary, no. 52).

Bauckham, R.J., 1993, The climax of prophecy: Studies on the Book of Revelation, Clark, Edinburgh.

Beale, G.K., 1999, The Book of Revelation: A commentary on the Greek text, Eerdmans, Grand Rapids. (NIGCT)

Beasley-Murray, G.R., 1974, Revelation, Eerdmans, Grand Rapids. (The New Century Bible Commentary).

Beckwith, I.T., 1922, The Apocalypse of John, MacMillan, New York.

Boring, M.E., 1989, Revelation, John Knox, Louisville. (Interpretation).

Caird, G.B., 1966, The Revelation of St John the divine, Clark, Edinburgh. (Black's New Testament Commentaries).

Chevalier, J.M., 1997, A Postmodern Revelation: Signs of astrology and the Apocalypse, UTP, Toronto.

Collins, A.Y., 1979, The Apocalypse, Liturgical Press, Collegeville.

Decock, P.B. 2012, 'Images of War and Creation, of Violence and Non-Violence in the Revelation of John', in P.G.R. de Villiers \& J.W. van Henten (eds.), Coping with Violence in the New Testament, pp. 185-200, Brill, Leiden. (Studies in Theology and Religion 16).

Desrosiers, G., 2000, An introduction to Revelation: A pathway to Interpretation, Continuum, London. (CBSS).

De Villiers, P.G.R., 1988, 'The Lord was crucified in Sodom and Egypt: Symbols in the Apocalypse of John', Neotestamentica 22, 125-138.

De Villiers, P.G.R., 2002, 'Rome in the historical interpretation of Revelation', Acta Patristica et Byzantina 13, 120-142.

De Villiers, P.G.R., 2007, 'Divine and human love in the Revelation of John', Acta Patristica et Byzantina 18, 43-59.

De Villiers, P.G.R., 2012, 'Hermeneutical Perspecives on Violence in the New Testament', in P.G.R. de Villiers \& J.W. van Henten (eds.), Coping with Violence in the New Testament, pp. 247-274 Brill, Leiden. (Studies in Theology and Religion 16).

Fekkes, J., 1994, Isaiah and prophetic traditions in the Book of Revelation: Visionary antecedents and their development, JSOT, Sheffield. (JSNTSSS 93).

Friesen, S., 2006, 'Sarcasm in Revelation 2-3: Churches, Christians, true Jews, and satanic synagogues', in D. Barr (ed.), The reality of Apocalypse: Rhetoric and Politics in the Book of Revelation, pp. 127-44, SBL, Atlanta.

Garrow, A.J.P., 1997, Revelation, Routledge, London. (New Testament Readings).

Giblin, C.H., 1991, The Book of Revelation: The Open book of prophecy, Liturgical, Collegeville. (Good News Studies, 34).

Gießen, H., 1997, Die Offenbarung des Johannes, Pustet, Regensburg. (Regensburger Neues Testament).

Hawhee, D., 2002, 'Agonism and arête', Philosophy and rhetoric 35, 185-207. http:// dx.doi.org/10.1353/par.2003.0004

Hellholm, D., Apocalypticism in the Mediterranean world and the Near East, Mohr, Tübingen.

Johnson, A.F., 1996, Revelation, Zondervan, Grand Rapids.

Kiddle, M., 1946, The Revelation of St. John, Hodder and Stoughton, London.

Knight, J., 1999, Revelation, Sheffield Academic Press, Sheffield. (Readings. A New Biblical Commentary).

Kraft, H., 1974, Die Offenbarung des Johannes, Mohr, Tübingen.

Ladd, G.E., 1972, A commentary on the Revelation of John, Eerdmans, Grand Rapids. Lohmeyer, E., 1953, Die Offenbarung des Johannes, Mohr, Tübingen. (HNT 16).

Maier, H.O., 2002, Apocalypse recalled: The Book of Revelation after Christendom, Fortress, Minneapolis.

Michaels, J.R., 1997, Revelation, InterVarsity, Downers Grove. (IVP New Testament Commentary Series).

Mounce, R.H., 1977, The Book of Revelation, Eerdmans, Grand Rapids. (NICC). 
Müller, U.B., 1995, Offenbarung, Herder, Wien.

Neville, D.J., 2007, 'Toward a Teleology of Peace: Contesting Matthew's Violen Eschatology', Journal for the Study of the New Testament 30, 131-61. http:// dx.doi.org/10.1177/0142064X07084773

Osborne, G.R., 2002, Revelation, Baker Academic, Grand Rapids. (BECNT.)

Prigent, P., 2001, Commentary on the Apocalypse of St. John, Mohr Siebeck, Tübingen.

Roloff, J., 1987, Die Offenbarung des Johannes, Theologischer Verlag, Zürich. (Zürcher Bibelkommentare, no. 18).

Satake, A., 1966, Die Gemeindeordnung in der Johannesapocalypse, Neurkirchener, Neukirchen. (WMANT 21).

Schüssler Fiorenza, E., 1981, Invitation to the Book of Revelation, Doubleday, New
Schüssler Fiorenza, E., 1998, The Book of Revelation, Fortress, Minneapolis. Sickenberger, J., 1942, Erklärung der Johannesapokalypse, Peter Hanstein, Bonn. Rowland, C., 1993. Revelation, Westminster, London. (Epworth Commentaries). Swete, H.B., 1911, The Apocalypse of St John: The Greek text with introduction, Notes and indices, MacMillan, London.

Thompson, L.L., 1990, The Book of Revelation: Apocalypse and empire, Oxford University Press, New York/Oxford.

Van Hartingsveld, L., 1985, Revelation, Eerdmans, Grand Rapids.

Van Schaik, A.P., 1971, De Openbaring van Johannes, Romen, Roermond. Visser, A.J., 1972, De Openbaring van Johannes, Callenbach, Nijkerk. 